\title{
NEUROLOGICAL EVALUATION OF CHILDREN AND ADOLESCENTS WITH BRAIN TUMOR, BASED ON AM BULATORY-ORIENTED FOLLOW-UP
}

\author{
Alexandre Serafim¹, Luiz Celso Pereira Vilanova², Najla Saba Silva ${ }^{3}$
}

\begin{abstract}
Taken as proved that brain tumors are the second most frequent childhood neoplasm - only outnumbered by leukemias - we have undertaken a clinical perspective study with seventy brain tumor patients ranging from one to fifteen years of age, throughout a four-year period (1993-1997), based on ambulatoryoriented follow-up. Forty-one male and twenty-nine female patients were analyzed, in that a slightly higher number of infratentorial tumors was observed (thirty-eight cases), compared to those supratentorially located (thirty-two cases). The most repeatedly observed during the study was the medulloblastoma (twenty-one patients), followed by the astrocytoma (fifteen patients) and the germinoma (eleven patients). It should be pointed out that during the ambulatory follow-up $75,5 \%$ of patients developed neurological sequels. A tumor recurrence was noticed in $34,3 \%$ of them, while $21,4 \%$ eventually died.
\end{abstract}

KEY WORDS: infratentorial, supratentorial, sequels, brain tumors.

\begin{abstract}
Avaliação neurológica de crianças e adolescentes com tumor cerebral através de acompanhamento ambulatorial

RESUMO - Considerando que os tumores cerebrais correspondem à segunda neoplasia mais freqüente na infância, sendo apenas superados pelas leucemias, realizamos um estudo clínico prospectivo em setenta pacientes com tumor cerebral, com idade variando de um a quinze anos, por um período de quatro anos (1993-1997), através de acompanhamento ambulatorial. Avaliamos quarenta e um pacientes do sexo masculino e vinte e nove do sexo feminino. Observamos uma freqüência discretamente maior de tumores infratentoriais (38 casos) em relação aos de localização supratentorial (32 casos). 0 tumor mais freqüentimente observado foi o meduloblastoma (21 casos), seguido pelo astrocitoma (15 casos) e pelo germinoma (11 casos). No acompanhamento ambulatorial, observamos que 75,5\% dos pacientes evoluíram com sequelas neurológicas. Em 34,3\% houve recidiva tumoral e $21,4 \%$ dos pacientes evoluíram para óbito.
\end{abstract}

PALAVRAS-CHAVE: infratentorial, supratentorial, sequelas, tumores cerebrais.

Brain tumors stand for the second most frequent neoplasm in children and adolescents, only outnumbered by leukemias ${ }^{1-7}$. The morbidity and mortality risks present in this pathology are distressful to family members, and patients' treatment-related tolerance hardly proves satisfactory. The quality of life in surviving patients is usually insufficient. The harmful effects of this pathology on patients' mental and physical health can be substantially reduced with early diagnoses, fast therapy start-up and multi-professional ambulatory-based follow-up, thus enabling greater support and comfort from family members.

The advances in neurological surgery techniques, plus the association of chemical agents and new radiotherapy techniques have been steadily enabling higher rates related to patients' survival and recovery ${ }^{8}$. Hence, our attention should be focused on improving these patients' quality of life.

Consequently, our major goal was the study of neurological clinical aspects related to children and adolescents with brain tumor diagnosis, based on perspective analyses and ambulatory-based followup. The analyses of patients' clinical evolution focused their neurological impairment, defining both the presence and absence of sequels. The study also comprised the correlation of these data with supra

São Paulo Federal University, São Paulo Medical School, São Paulo SP, Brazil (UNIFESP-EPM): ${ }^{1}$ Master's Degree in Pediatric Neurology granted by UNIFESP-EPM, Pediatrics Assistant Professor at the University of Taubaté, SP; ${ }^{2}$ Professor of Child Neurology and Chairman of Division of Child Neurology Department of Neurology and Neurosurgery-Division of Child Neurology UNIFESP-EPM; ${ }^{3}$ Master's Degree in Pediatrics granted by UNIFESP-EPM, Head of the Pediatric Neuro-oncology Division at UNIFESP-EPM.

Received 21 February 2001, received in final form 2 July 2001. Accepted 21 July 2001.

Dr. Alexandre Serafim - Av. Juscelino K. de Oliveira 500/31 - 12010-600 Taubaté SP - Brasil. 
or infratentorial tumor location, just as aspects regarding their histology type, tumor recurrences and deaths involved.

\section{METHOD}

The study was carried out at the Pediatric Oncology Ambulatory of the São Paulo Federal University- São Paulo Medical School (UNIFESP-EPM), from early March 1993 through March 1997. Seventy patients with brain tumor diagnosis were examined, in that 41 were male and 29 female, ranging from 1 to 15 years of age.

The brain tumor location was determined by cranial computed tomography and/or nuclear magnetic resonance, defining tumors located above the tentorium cerebeli as supratentorial (32 tumors), and those below as infratentorial (38 tumors).

The tumor histology type was confirmed through anatomic-pathological analyses, duly organized in accordance with the brain tumor classification of the World Health Organization (WHO) ${ }^{9}$. Pursuant to the aforementioned classification, the following data were obtained: 29 patients with embryonal tumors ( 21 cases of medulloblastoma and 8 cases of neuroectodermal primitive tumors), 25 patients with neuroepithelial tumors (14 cases of astrocytoma, 3 cases of ependymomas, 3 cases of glioma, 2 cases of glioblastoma multiforme, 1 case of multiform ganglioma, 1 case of oligodendroglioma and 1 case of oligoastrocytoma), 11 patients with germinal cell tumors (all germinomas); 5 patients with less frequent tumors were grouped in our analysis as other tumors ( 2 cases of neurofibroma, 1 case of craniopharyngioma, 1 case of esthesioneuroblastoma and 1 case of Ewin's sarcoma metastasis).

All patients were submitted to the initial neurological clinical evaluation; later on, their follow-up was conducted on ambulatory-oriented basis, with reevaluations made every 3 months. The minimum follow-up period comprised twelve months, while the maximum involved forty-eight. Therefore, the study relied on perspective analyses and ambulatory-based follow-up, which defined patients' clinical evolution and neurological impairment, both focusing the presence or absence of sequels.

The data obtained were compared with the supra or infratentorial tumor location, their histology type, eventual tumor recurrences and deaths. All patients included in the study did not present neurological disorders prior to their current illness.

\section{Statistical method}

Nonparametric tests were used to analyze the results, taking into consideration the nature of variables studied. The following tests were applied: 1 . Chi square test (for contingency tables ${ }^{10}$, in order to compare the supratentorial or infratentorial tumor location, as far as the clinical evolution is concerned (types of disorders observed over the last neurological examination), according to tumor histology type and corresponding recurrence; 2 . Fisher exact test ${ }^{10}$, for the study of clinical evolution as regards the occurrence of deaths, taking the Cochran restrictions into consideration; 3. Mc Nemar test ${ }^{11}$, geared to individually compare the presence or absence of neurological sequels, which was observed both over the first and last neurological evaluations, respectively.

The null hypothesis rejection level was fixed in 0.05 or $5 \%$ for all tests, in that significant values were identified with an asterisk.

\section{RESULTS}

The ambulatory follow-up enabled the identification of 57 patients who eventually developed neurological sequels, whereas 13 of them did not (Table 1). These data were then compared to the tumor histology type (Table 2), its supra or infratentorial location (Table 3), recurrence (Table 4) and deaths (Table 5).

\section{DISCUSSION}

The highest survival rates in brain tumor patients have been reported in literature ${ }^{4,12-15}$ as connected to improvement of surgical techniques and specific treatment-related guidelines according to tumor histology type, as far as the use of different chemical agents, dose variations and advances in the use of radiotherapy are concerned. Consequently, a growing number of patients are achieving a longer life span, which enables an improved analysis of neurological disorders as regards patients' clinical evolution. Brain tumor cases observed in individuals under fifteen years of age display a slight predominance of tumor occurrence in male patients, when compared to female patients ${ }^{2,16-22}$, just as the infratentorial location prevails over the supratentorial ${ }^{14,17,23-26}$. Regarding the histology type, the medulloblastoma and the astrocytoma have respectively been the most frequently reported within this age bracket. Data obtained in our series were in compliance with the aforementioned literature.

The ambulatory-oriented follow-up enabled the observation that clinical evolution involving neurological sequels prevailed over all histology types. This predominance did not change as regards the supratentorial and infratentorial location of tumors, nor concerning tumor recurrence. The occurrence of neurological sequels prevailed in patients who eventually died (15 cases); however, the statistical analysis was not significant (Table 5).

References to neurological sequels during the follow-up conducted for brain tumor diagnosed patients and regarding the supratentorial or infraten- 
Table 1. Clinical evolution of patients as far as the last neurological evaluation is concerned.

\begin{tabular}{|c|c|}
\hline Clinical evolution & № \\
\hline Normal & 13 \\
\hline Ataxia + Dysmetria + Cranial Nerve (VII) & 5 \\
\hline Hemiparesis & 3 \\
\hline Epilepsy & 3 \\
\hline Dual Hemiparesis + Cranial Nerve (IV) + Epilepsy & 2 \\
\hline Visual Impairment + Cranial Nerve (III) & 2 \\
\hline Hearing Impairment & 2 \\
\hline Dysmetria & 2 \\
\hline Visual Impairment + Precocious Puberty & 2 \\
\hline Crural Diparesis & 2 \\
\hline Hemiparesis + Epilepsy & 2 \\
\hline Monoparesis + Hearing Impairment & 1 \\
\hline Visual Impairment + Epilepsy & 1 \\
\hline $\begin{array}{l}\text { Dual Hemiparesis + Ataxia + Dysmetria } \\
+ \text { Hearing Impairment + Panhypopituitarism }\end{array}$ & 1 \\
\hline Cranial Nerve (III) + Dysmetria & 1 \\
\hline Precocious Puberty & 1 \\
\hline Epilepsy + Diabetes Insipidus & 1 \\
\hline Ataxia + Dysmetria + Epilepsy & 1 \\
\hline Dysmetria + Ataxia + Dysarthria & 1 \\
\hline Dual Hemiparesis + Cranial Nerve (VI,VII,IX,X) & 1 \\
\hline Dual Hemiparesis + Dysmetria & 1 \\
\hline Hemiparesis + Dysmetria & 1 \\
\hline Crural Monoparesis + Dysmetria & 1 \\
\hline Hearing Impairment + Cranial Nerve (IV) & 1 \\
\hline $\begin{array}{l}\text { Dual Hemiparesis + Ataxia + Dysmetria } \\
\quad+\text { Cranial Nerve }(I X, X, X I)\end{array}$ & 1 \\
\hline Diabetes Insipidus & 1 \\
\hline Hemiparesis + Epilepsy + Hearing Impairment & 1 \\
\hline Diabetes Insipidus + Visual Impairment & 1 \\
\hline Dysmetria + Epilepsy & 1 \\
\hline Monoparesis + Epilepsy & 1 \\
\hline Hemiparesis + Cranial Nerve (II,III,IV,VI) + Epilepsy & 1 \\
\hline Cranial Nerve (IV) + Visual Impairment + Epilepsy & 1 \\
\hline Cranial Nerve (III,IV,VI) & 1 \\
\hline Hearing Impairment + Diabetes Insipidus & 1 \\
\hline Dual Hemiparesis & 1 \\
\hline Crural Diparesis + Dysmetria + Ataxia & 1 \\
\hline Dysmetria + Hearing Impairment & 1 \\
\hline Dual Hemiparesis + Epilepsy & 1 \\
\hline Monoparesis + Hearing Impairment & 1 \\
\hline Hemiparesis + Ataxia + Dysmetria & 1 \\
\hline Hemiparesis + Cranial Nerve (III,IV) & 1 \\
\hline Triparesis + Epilepsy & 1 \\
\hline Dual Hemiparesis + Dystonia + Epilepsy & 1 \\
\hline
\end{tabular}

Tabela 2. Patients with brain tumor diagnosis; presence of sequels according to the clinical evolution and absence in accordance with the last neurological clinical examination, as regards the tumor histology type.

\begin{tabular}{lcccccc}
\hline \multirow{2}{*}{ Tumors } & \multicolumn{3}{c}{ Clinical evolution } & \multicolumn{2}{c}{ Total } \\
\cline { 2 - 5 } & $\begin{array}{l}\text { Presence } \\
\text { of sequels }\end{array}$ & $\begin{array}{c}\text { Absence } \\
\text { of sequels }\end{array}$ & & \\
\cline { 2 - 5 } & $\mathrm{N}$ & $\%$ & $\mathrm{~N}$ & $\%$ & $\mathrm{~N}$ & $\%$ \\
\hline Embryon. t. & 20 & 68.9 & 9 & 31.1 & 29 & 100 \\
Other neuroep. t. & 23 & 92 & 2 & 8 & 25 & 100 \\
Germ. cel. t. & 10 & 90.9 & 1 & 9.1 & 11 & 100 \\
Other tumors & 4 & 80 & 1 & 20 & 5 & 100 \\
Total & 57 & 81.4 & 13 & 18.6 & 70 & 100 \\
\hline
\end{tabular}

Embyon. t, Embryonal tumors; Other neuroep. t, Other neuroepithelial tumors; Germ. cel. t, Germinal cell tumors; Chi square test: Calculated Value $=5,487$; Critical value $=7,81$

Table 3. Patients with brain tumor diagnosis; presence of sequels according to the clinical evolution and absence in accordance with the last neurological clinical examination, as regards brain tumor supratentorial or infratentorial location.

\begin{tabular}{|c|c|c|c|c|c|c|c|}
\hline \multirow[t]{3}{*}{ Location } & \multicolumn{4}{|c|}{ Clinical evolution } & \multicolumn{2}{|c|}{ Total } & \multirow{3}{*}{$\begin{array}{c}\text { Sequels } \\
\qquad \%\end{array}$} \\
\hline & \multicolumn{2}{|c|}{$\begin{array}{l}\text { Presence } \\
\text { of sequels }\end{array}$} & \multicolumn{2}{|c|}{$\begin{array}{l}\text { Absence } \\
\text { of sequels }\end{array}$} & \multirow[b]{2}{*}{$\mathrm{N}$} & \multirow[b]{2}{*}{$\%$} & \\
\hline & $\mathrm{N}$ & $\%$ & $\mathrm{~N}$ & $\%$ & & & \\
\hline Supratentorial & 27 & 47.4 & 5 & 38.5 & 32 & 45.7 & 84.4 \\
\hline Infratentorial & 30 & 52.6 & 8 & 61.5 & 38 & 54.3 & 79.9 \\
\hline Total & 57 & 100 & 13 & 100 & 70 & 100 & 81.4 \\
\hline
\end{tabular}

Chi square test: Observed value $=0.18$; Critical value $=3,84$.

Table 4. Patients with brain tumor diagnosis; existence of sequels according to the clinical evolution and inexistence in accordance with the last neurological examination, as regards presence and/or absence of tumor recurrence.

\begin{tabular}{lccccccc}
\hline \multirow{2}{*}{ Recurrence } & \multicolumn{3}{c}{ Clinical evolution } & & \multicolumn{2}{c}{ Total } \\
\cline { 2 - 6 } & \cline { 2 - 6 } & \multicolumn{2}{c}{ Sequel } & \multicolumn{2}{c}{ Normal } & & \\
\cline { 2 - 6 } & $\mathrm{N}$ & $\%$ & $\mathrm{~N}$ & $\%$ & & $\mathrm{~N}$ & $\%$ \\
\hline Present & 24 & 88.9 & 3 & 11.1 & 27 & 100 \\
Absent & 33 & 76.7 & 10 & 23.3 & 43 & 100 \\
Total & 57 & 81.4 & 13 & 18.6 & 70 & 100 \\
\hline
\end{tabular}

Chi square test: Observed value $=1,15$; Critical value $=3,84$. 
Table 5. Patients with brain tumor diagnosis; presence of sequels according to the clinical evolution and absence in accordance with the last neurological evaluation, as regards occurrence of deaths.

\begin{tabular}{|c|c|c|c|c|}
\hline \multirow[t]{3}{*}{ Deaths } & \multicolumn{2}{|c|}{ Clinical evolution } & \multirow{3}{*}{$\begin{array}{c}\text { Total } \\
\text { N }\end{array}$} & \multirow{3}{*}{$\begin{array}{c}\text { Deaths } \\
\quad \%\end{array}$} \\
\hline & \multirow{2}{*}{$\begin{array}{c}\text { Yes } \\
\mathrm{N}\end{array}$} & \multirow{2}{*}{$\frac{\text { No }}{N}$} & & \\
\hline & & & & \\
\hline Presence of sequels & 12 & 45 & 57 & 21.1 \\
\hline Absence of sequels & 3 & 10 & 13 & 23.1 \\
\hline Total & 15 & 55 & 70 & 21.4 \\
\hline
\end{tabular}

Fisher exact test; $\mathrm{P}=0.5661$

torial tumor location were not observed in literature.

Brain tumor histological characteristics, with respect to their higher or lower level of malignancy, in addition to analyses comprising their endothelial proliferation capacity, necrosis, mitotic activity, nuclear atypia, brain tissue infiltration or compression caused by mass effect in structures of the nervous system are the major aspects that will eventually determine a better or worse prognosis, as far as patients' evolution is concerned, both in terms of survival and quality of life $e^{4,15}$.

It should be mentioned that the brain tumor treatment in itself (including surgeries, radiotherapy, chemotherapy) is harmful to the brain tissue, thus increasing the risk of sequels.

The neurological disorders in surviving patients are related to the type of tumor and side effects on impaired structures, therapeutic methods applied and patients' age $\mathrm{e}^{13,27-32}$.

Radiotherapy can cause tardive effects on the brain tissue ${ }^{14,27,31,32}$ and lead to alterations, namely, leukoencephalopathies, formation of oncogenic areas, neuroendocrine disorders, and cognitive disorders ${ }^{4,33-35}$. The neuroendocrine disorders are also perceived in children submitted to radiotherapy, and one of the major damages is the alteration of the growth hormone secretion ${ }^{13}$. Less frequently observed disorders are related to the secretion of gonadotrophins, panhypopituitarism and secondary hypothyroidism ${ }^{36}$.

During the evaluation of practice-related abilities in 342 adults who reported brain tumors under 20 years of age, Mostow et al. ${ }^{36}$ observed inability connected to driving and conducting professional ac- tivities when compared to a normal control group. These results were mainly present in patients with story of supratentorially located tumors and those submitted to radiotherapy, which led us to conclude that the standards related to quality of life in these patients is low.

Within the prognosis of brain tumor-diagnosed patients, the tumor recurrence and the involvement of death is directly related to lower ages in tumor occurrences, as well as to its histology type, malignancy level, difficulties in tumor surgical resection and the possibility of using proper radiotherapy doses $^{2,8,12,17}$.

Therefore, our study complies with the literature analyzed, showing both the prompt and tardive harmful effects related to the existence of a nervous system tumor, impairing patients' health and survival.

\section{REFERENCES}

1. Maroldo TV, Barkowich AJ. Pediatric brain tumors. Seminars in Ultrasound. CT and MR.1992;412-448.

2. Mueller BA, Gurney JG. Epidemiology of pediatric brain tumors. Neurosurg Clin N Am 1992;3:715-721.

3. Cohen ME, Duffner PK. Tumors of the brain and spinal cord including leukemic involvement. In Kenneth FS (ed). Pediatric neurology. 29.Ed. St. Louis: Mosby, 1993:887-950.

4. Heideman R, Packen PJ, A lbert LA, Freeman CR, Rorke LB. Tumors of the central nervous system: principles and practice of pediatric oncology 2.Ed., Philadel phia: Lippincott, 1993.

5. Stiller CA, Nectoux J. International incidence of childhood brain and spinal tumors. Int J Epidemiol 1994;23:458-464.

6. Hesseling PB, Wessels G, Riet FA. The Tygerberg Hospital Children's tumor registry 1983-1993. Eur J Cancer 1995;31:1471-1475.

7. Marina MN, Bowman CL, Pui C, Crist WN. Tumores sólidos infantiles. Manual de la A merican Cancer Society. Organización Panmericana de la Salud. Publicación Científica 559. 2.Ed. Memphis: Tennessee, 1996:587-592.

8. Duffner PK, Cohen ME, Myers MH, Heise HW. Survival of children with brain tumors: Seek Program 1973-1980. Neurology 1986;36:597601.

9. Kleihues P, Burger PC, Scheithauer BW. Histologyal typing of tumors of the central nervous system. 2.Ed. Berlin: Springer-Verlag, 1993:1-10.

10. Siegel S, Castellan NJ Jr. Nonparametric statistics. 2.Ed. New York: MacGraw-Hill, 1988:399.

11. Remington RD, Schork MA. Statistics with applications to biological and health sciences. N ew Jersey: Prentice-Hall, Englewood Cliffs, 1970.

12. Duffner PK, Cohen ME, Thomas PR, Lansky SB. Long-term effects of cranial irradiation of the central nervous system. Cancer 1985;56:18411846.

13. Lannering B, Marky I, Nordburg C. Brain tumors in childhood and adolescents in West Sweden 1970-1984. Cancer 1990;66:604-609.

14. Otsubo H, H offman HJ, Humphrey's RP, et. al. Detection and management of gangliomas in children. Surg. Neurol 1992;38:371-378.

15. Cohen M, Hynd G, Hugdahl K. Dichotic listening performance in subtypes of developmental dyslexia and a left temporal lobe brain tumor contrast group. Brain Lang 1992;42:187-202.

16. Thapar K, Laws ER. Tumores del sistema nervioso central. Oncologia clínica: manual de la A merican Cancer Society., Organización Panmericana de la Salud. Publicación Científica 559. 2.Ed. Memphis: Tennessee, 1996:425-461.

17. YoungmJL, Miller RN. Incidence of malignant tumor in U.S. children. J Pediat 1975;86:254-258

18. Peacock NJ, Lazaref JA, Levin CV. Childhood brain tumors in Cape Town. S Afr Med J 1987;71:5-8. 
19. Brown PN, Hentz H, Olsen JH, Yssing M, Scheilbel E, Jensen OM. Incidence of childhood cancer in Denmark 1943-1984. Int J Epidemiol 1989;18:546-555.

20. Torres LF, Almeida R, Avila S, Alessi S, Freitas R. Brain tumors up South Brazil: a retrospective study of 438 cases. Arq Neuropsiquiatr 1990;48:279-285.

21. Crowley MJ, Brien DF. Epidemiology of tumors of the central nervous system in Ireland. Ir Med J 1993;86:87-88.

22. Miltenburg D, Coun DF, Sutherland GR. Epidemioncology of childhood brain tumors. Can J Neurol Sci 1996;23:118-122.

23. Davis FG, Maynski N, Haenszel W, et al. Primary brain tumor incidence: rates in four United States regions, 1985-1989. A pilot study. Neuroepidemiology 1996;15:102-103.

24. Gilles FH, Leviton A, HedleET, et al. Childhood brain tumors that occupy more than one compartment at preservation. J Neurooncol 1992;14:45-56.

25. Tewari MK, Sharma BS, Mahajan RK, et al. Supratentorial tumors in infants. Childs Nerv Syst 1994;10:172-175.

26. Bondy $M L$, Wrensch MR. Epidemiology of primary malignant brain tumors. Brillieres Clin Neurol 1996;5:251-270.

27. Reed UC, AImeida GGM. Tumores intracranianos. In Diament A, Cypel S (eds). Neurologia infantil, 3.Ed. São Paulo:A theneu, 1996;1019-1042.
28. Banford FN, Morris-Jones P, Pearson D. Residual disabilities in children treated for intracranial spaceoccupying. Cancer 1976;37:1149-1151.

29. Li AP, Stone R. Survivors of cancer in childhood. Ann Intern Med 1976;84:551-553.

30. Copeland DR, Moore B. Neuropsychological effects of chemoterapy on children 3-5 years old at diagnosis. Proc Am Soc Oncol 1991;10:346-349.

31. Shang EG, Scheithaver BW, O'Fallow JR - Supratentorial gliomas: a comparative study by grade and histology type. J Neurooncol 1997; 31:273-278.

32. Deutsch $M$. Radiotherapy for 10 primary brain tumors in very young children. Cancer 1982;50:2785-2789.

33. Moore B, Copeland D, Ater JR. Neuropsychological effects of cranial radiation therapy in patients with brain tumors in infancy. J Clin Exp Neuropsychol 1991;13:98-102.

34. Duffner PK, Cohen ME, Thomas PR. Late effects of treatment on theintelligence of children with posterior fossa tumors. Cancer 1983;51:233-237.

35. Livesey EA, Hina-Marsh PO, Brook CGD. Endocrine disorders following treatment of childhood brain tumors. Br J Cancer 1990;61:622-625.

36. Mostow EN, Byrne J, Connely PR, Mulvihill JJ. Quality of life in long team survivors of CNStumors of childhood in adolescence.J Clin Oncol 1991;9:592-599. 